\title{
Mixed crustaceosis infestation at black-head minnows
}

\section{O. Oliynyk,}

Ichthyopathological laboratory of State Agency of Fisheries of Ukraine E. Oliynik

N. Matviyenko,

Doctor of Biological Sciences, Senior Researcher, Institute of Fisheries of the National Academy of Agricultural Sciences of Ukraine

\section{Mandygra,}

Doctor of Veterinary Sciences, corresponding member of NAAS, academician-secretary of the Department of Veterinary Medicine NAAS

National Academy of Agricultural Sciences of Ukraine

The purpose. To analyze peculiar features of diagnostics, seasonal prevalence and clinical attributes at blackhead minnows at admixed crustaceosis infestations. Methods. Methods of clinical inspection and incomplete parasitologic opening. Results. Data concerning clinical attributes of parasitizing of agents of crustaceosis are obtained. It is determined that in summer flash of Lernaeosis Lernaea (at different stages of growth, except for puberal) can be located on gills of a fish. Conclusions. Simultaneous parasitizing on a fish of different agents of crustaceosis infestation can be observed more often in the spring-and-summer season. At admixed crustaceosis infestation the agent of Lernaeosis, in comparison with agents of arguleosis, sinergasileosis and ergasileosis prevails.

Key words: arguleosis, Argulus, ergasileosis, Ergasilus, crustaceosis, Lernaeosis, Lernaea, sinergasileosis, Sinergasilus.

Introduction (problem statement). Aquaculture of Ukraine is one of the most important sectors of country's agriculture. The development of aquaculture is slowed down by the high level of morbidity of reared hydrobionts. Crustacean diseases are sufficiently widespread among hydrobionts' diseases [1]. Crustacean diseases are dangerous not only as a monoinvasion (argulosis, lernaeosis, synergasilosis, ergasilosis), but as the mixed invasion of crustaceans, that causes serious negative consequences for fish organism. There are no works, devoted to peculiarities of symptoms of the mixed invasion of crustaceans among publications in our country. Considering the real situation in specialized fish farms, this problem is noteworthy and has to be studied in detail.

Analysis of latest researches and publications on studied subject. The most prevalent causative agents of crustacean diseases of fresh-water fishes in specialized Ukrainian fish farms are agents of such genus as Ergasilus, Sinergasilus, Lernaea and Argulus.

The practice of last years reveals that crustacean diseases are frequently found in fish farms supplied by water of Dnipro River's cascade of reservoirs. Those invasions inflict material damage to fish farms. The damage mentioned is made by loss of weight increase, by death of fry, considerably affected by parasites, and by loss of saleable fish condition [2].

Crustacean diseases are diagnosed on the basis of clinical, epizootiological findings and microscopy [3]. In order to find Argulus and Lernaea fish body surface is examined by naked eye and using magnifying glass. In order to find Ergasilus and Sinergasilus, gill mucus and strips of gill tissues are examined using microscope [4]. Lernaeosis and argulosis should be distinguished from diseases with syndrome of «red spot disease» (Spring viraemia of carp, aeromonosis, pseudomonosis). Lernaeosis is diagnosed when the quantity of Lernaea cyprinacea that parasites on one carp fry with body weight of $0,5-5,0 \mathrm{~g}$ is more than 1 specimen; ergasilosis is diagnosed when the quantity of Ergasilus sieboldi is more than 1-2 specimens; argulosis is diagnosed when the quantity of Argulus foliaceus is more than 1 specimen and protein concentration in carp fry blood serum is less than $2 \%$ [5].

Thus, after analyzing results of researches, made by different authors, we can state that crustacean diseases are important problems for specialized fish farms; those diseases affect fish quality and its saleable condition adversely. 
Objects and methods of study. Throughout the 2009-2016 years, examination of carp fishes was carried out on the base of the state enterprise «Irklievsky phytophagous fish farm» (Chornobayvsky region, Cherkas'ka Oblast'). Two-year carp fishes (carp, spotted silver carp, grass carp in quantity of not less than 100 specimens) were examined using methods of clinical examination and incomplete parasitological dissection [6] for occurrence of crustaceans while monitoring the dynamic of arousal of mixed invasion of crustaceans.

Results. It was found out that at the examined farm two-year carp fishes' affection by causative agents of crustacean diseases more frequently had a character of the mixed invasion and less frequently - a character of monoinvasion (especially lernaeosis). It was also found out that crustaceans parasitize on fish in different combinations, as shown in Table 1.

Table 1. Causative agents of mixed invasion of crustaceans of two-year carp fishes

\begin{tabular}{|l|l|l|l|l|}
\hline Fish species & Argulus & Lernaea & Ergasilus & Sinergasilus \\
\hline Carp & + & + & & \\
\cline { 2 - 6 } & & + & + & \\
\hline Spotted silver carp & + & + & & \\
\cline { 2 - 6 } & & + & & + \\
\hline Grass carp & & + & & + \\
\hline
\end{tabular}

Cases of simultaneous parasitizing of three various crustaceans on one host were not observed, in spite of their occurrence in different combinations on fishes from the same pond. Probably it is related to the fact that such affection may cause sharp collapse and precipitate fish death.

In Table 2, peculiarities, that were found during the studying of seasonality and course of invasion of crustaceans of two-year carps and phytophagous fishes, are shown.

Table 2. Seasonality of mixed invasion of crustaceans of two-year carps ( $n=100, M \pm m)$.

\begin{tabular}{|l|l|l|l|}
\hline Month & Revealed crustaceans & Frequency of invasion & Numbers-per-host \\
\hline February & Lernaea & \multicolumn{2}{|l|}{ Signs of parasitizing } \\
\hline March & Argulus & 14 & $3 \pm 1,4$ \\
\hline April & Argulus/ Lernaea & $16 / 24$ & $3 \pm 2,3 / 6 \pm 2$ \\
\hline May & Lernaea/ Argulus & $34 / 18$ & $8 \pm 0,82 / 7 \pm 2,6$ \\
\hline June & Lernaea/ Ergasilus & $39 / 30$ & $10 \pm 2,2 / 6 \pm 1,6$ \\
\hline July & Lernaea & 38 & $6 \pm 2,3$ \\
\hline August & Lernaea/ Ergasilus & $34 / 15$ & $7 \pm 2,1 / 3 \pm 0,8$ \\
\hline September & Lernaea/ Argulus & $23 / 14$ & $5 \pm 1,1 / 3 \pm 0,9$ \\
\hline October & Argulus/ Lernaea & $5 / 20$ & $4 \pm 1,4 / 5 \pm 1,2$ \\
\hline November & Lernaea & Signs of parasitizing & \\
\hline
\end{tabular}


Table 3. Seasonality of mixed invasion of crustaceans of phytophagous fishes (spotted silver carp, grass carp) $(n=100, M \pm m)$.

\begin{tabular}{|c|c|c|c|}
\hline Month & Revealed crustaceans & Frequency of invasion & Numbers-per-host \\
\hline March & Lernaea & 10 & $2 \pm 1,12$ \\
\hline \multirow[t]{2}{*}{ April } & Argulus*/Lernaea* & $18 / 21$ & $5 \pm 0,98 / 7 \pm 2,6$ \\
\hline & Sinergasilus* & 24 & $6 \pm 0,89$ \\
\hline May & Argulus/ Sinergasilus & $34 / 26$ & $8 \pm 1,04 / 9 \pm 1,1$ \\
\hline \multirow[t]{2}{*}{ June } & Lernaea & 24 & $11 \pm 2,4$ \\
\hline & Sinergasilus & 23 & $8 \pm 0,9$ \\
\hline July & Lernaea & 20 & $9 \pm 2,03$ \\
\hline \multirow[t]{2}{*}{ August } & Lernaea & 25 & $8 \pm 2,1$ \\
\hline & Sinergasilus & 22 & $7 \pm 1,2$ \\
\hline September & Sinergasilus & 21 & $5 \pm 1,06$ \\
\hline October & Sinergasilus & 15 & $3 \pm 1,23$ \\
\hline
\end{tabular}

Analyzing data, shown in Tables 2 and 3, one can conclude that mixed invasion of crustaceans of carp fish appears usually in April and persists until June. Lernaeosis is diagnosed as a monoinvasion of carp in July-August (except for sporadic occurrence of parasitizing of single specimens of Ergasilus in August). Mixed invasion of crustaceans of carp is registered again at the beginning of the autumn. Mixed invasion of crustaceans of phytophagous fishes is registered also in August, but in the autumn only parasitizing of Sinergasilus is registered.

The absence of parasitizing of Argulus in summer months is related to intensive medioprophylactic fish treatment at the farm during fish transfers in May and with taking of complex piscicultural improvement measures, that gives an opportunity to stop development of invasion. Simultaneous detection of Argulus and Lernaea in September-October can be explained by mixing of fishes from different ponds during autumn fish transfers. Attenuation of intensity of crustacean invasion in November can be explained by fall of temperature and additional medioprophylactic fish treatment during transfers, and later, in the hibernating ponds.

In carp, Argulus is frequently located on the area of pectoral fins, near the head (single specimens), and around the basis of caudal fin and on caudal fin. Single specimens of Argulus were found on pectoral fins and dorsal fin.

Lernaea was found in carp on the area of abdomen (2-7 specimens), on lateral fish surfaces - 3-10 specimens, sometimes on the surface of dorsal fin and caudal fin.

Considerable reddening and small haemorrhages of $2-5 \mathrm{~mm}$ in size were found at the places of Argulus localization. Haemorrhages and different sized ulcers $(3-20 \mathrm{~mm})$ with red borders and attached Lernaea were found in the places of Lernaea localization. In neglected cases deep ulcer, penetrative to the muscles, with considerable necrotized areas and tegument affection was found. During inconsiderable invasion in the early spring, Lernaea was located mainly under the scales, and haemorrhages $(2-3 \mathrm{~mm}$ in size) were also found there. Lernaea at different stages of development (except pubescent one) were often found in the course of microscopy of gill scraping during 
Lernaea monoinvasion outbreaks in summer. Thus, Lernaea may attach not only to the fish surface, but also to the gills.

Changes that become apparent during diseases with syndrome of «red spot disease» - scales dishevelling, ulcers and haemorrhages on fish surface - were detected during Lernaea outbreaks in summer months. However, Lernaea was not always present on the fish surface. Distinctive scale injuries only affirmed the parasitizing: scale borders were rugged, with different size cavities - like «gnawed».

In autumn (October) body surface of two-year carps was covered by greyish inordinate matt mucus layer. We found a lot of small Argulus during examining of that mucus using microscope. These causative agents adapt to oncoming winter that way.

Sporadic occurrences of Ergasilus parasitizing on gills of two-year carps and Lernaea on fish body surface were registered at the state enterprise «Irklievsky phytophagous fish farm». At the same time, considerable haemorrhages and ulcers were found on the fish surface; fish gills were dark cherry red with necrotized areas on gill lamellae borders. Inconsiderable quantity of Ergasilus (carriage) was also detected on gills using microscope; at that pathological changes in gills resembled similar pathology in the case of considerable intensity of synergasilosis of phytophagous fishes.

Localization of Argulus and Lernaea on phytophagous fishes was similar: Argulus and Lernaea more frequently localized on fish abdomen on the area from pectoral fin to anus, and less frequently on the lateral surfaces and fins. Also Argulus was often located near the basis of caudal fin. Small haemorrhages (2-5 $\mathrm{mm}$ in size) were found at the places of Argulus localization. At the places of parasitizing of Lernaea ulcers (3-10 $\mathrm{mm}$ in size) were frequently found.

Phytophagous fish's gills were often swollen, at the high intensity of invasion its surface was covered by inordinate mucus. Moreover, phytophagous fish's gills frequently had marmoreal coloration during Sinergasilus infestation - in other words, large areas of gills were necrotized and other areas on the contrary were blood-filled. In addition, during the high intensity of invasion, grey areas were found on the gill lamellae borders (necrotized areas of gill tissues) along with specimens of Sinergasilus in the form of greyish yellow threads with branches on the ends.

So, Argulus and Lernaea more frequently attach to places, where scales are small, and not as firm and strong as on the lateral body surfaces.

Parasitizing of Lernaea and Argulus is characterized by haemorrhages and elcosis. In the case of invasion outbreak, scales raising and dishevelling also takes place. That can be result of penetration of pathogenic microflora into open wounds, formed by the parasite activity and development of secondary infectious diseases.

Parasitizing of Ergasilus and Sinergasilus causes gill tissues necrosis, swollen gills and inordinate sliminess. Since gills are fish respiratory organs, those changes affect its physiological state. Upon oxygen impoverishment in water such fish is killed by the asphyxia faster, because safe gill area can not provide enough oxygen to organism.

Our results prove that different authors' findings about clinical signs of parasitizing of crustaceans are true: parasitizing of Argulus on the body surface of different fish causes appearance of swellings, haemorrhages and ulcers $[7,8]$ and also causes development of secondary diseases [9, 10]; parasitizing of Lernaea on the fish body surface [11, 12] also causes appearance of similar clinical signs. Parasitizing of Ergasilus on fish gills causes inflammation, epithelial gill lamellae destruction, gill tissue necrosis, fish organism intoxication [4, 13]; parasitizing of Sinergasilus causes inflammation, gill swelling, paling because of disturbed blood circulation, gill tissue necrotizes [3, 4].

In contrast to data, available in published works, we found that Lernaea at different stages of development (except pubescent one) may be localized on the gills of carp fishes.

\section{Conclusion}

Simultaneous parasitizing of various crustaceans on fish is more common in spring and summer period. In the process of mixed invasion of crustaceans, Lernaea parasites are prevalent compared to Argulus, Sinergasilus and Ergasilus ones. Obtained results can become a base for wide investigation of host-parasite interaction system for different fish species. 


\section{References}

1. Bozhyk V.I. (2010). Profilaktyka ta borotba $z$ khvorobamy ryb $v$ rybhospodarstvakh Zakhidnoi Ukrainy. Optymalne vykorystannia, zberezhennia i vidtvorennia vodnykh zhyvykh resursiv - nahalni zavdannia tovarovyrobnykiv ryboproduktsii ta naukovykh ustanov rybnoi haluzi: materialy naukovo-praktychnoho seminaru, 12.06.2009. Kyiv, MA: NTUU «KPI», 109-114.

2. Prosiana V. (2006). Khvoroby, shcho psuiut tovarnyi vyhliad ryb. Veterynarna medytsyna Ukrainy, 5, $39-42$.

3. Golovina N.A., Bauer O.N. (2007). Ikhtiopatologiya. Moscow, MA: Mir.

4. Temnikhanov lu.D. (2015). Khvoroby stavkovykh ryb (profilaktyka ta likuvannia). Vinnytsia, MA: TOV «NilanLTD».

5. Davydov O.M. (1998). Suchasni aspekty ozdorovlennia ryb v akvakulturi. Kyiv, MA: Instytut zoolohii NAN Ukrainy.

6. Musselius V.A., Vanyatinskiy V.F., Vikhman A.A. (1983). Laboratornyy praktikum po boleznyam ryb. Moscow, MA: Legkaya i pishchevaya promyshlennost.

7. Braginskiy L.P. (1996). Ekologicheskaya ekspertiza prichin massovoy gibeli ryb. Kiyev, MA: Institut zoologii NAN Ukrainy.

8. Davidov O.N., Neborachek S.I., Kurovskaya L.Ya., Lysenko V.N. (2011). Ekologiya parazitov ryb vodoyemov Ukrainy. Kiyev, MA: Vestnik zoologii.

9. Kumar S., Raman R. P., Pandey P. K., Kumar N., Mallesh B., Mohanty S., Kumar A. (2012). Effect of azadirachtin on haematological and biochemical parameters of Argulus-infested goldfish Carassius auratus (Linn. 1758). Fish physiology and biochemistry. - Springer Science+Business Media Dordrecht. doi 10.1007/s10695-0129736-8

10. Öktener A., Ali A.H., Gustinelli A., Fioravanti M.L. (2006). New host records for fish louse, Argulus foliaceus L., 1758 (Crustacea, Branchiura) in Turkey. Ittiopatologia, 2006 (3), 161-167.

11. Patent 70312, Ukraina, MPK (2012.01) A01K 61/00 A61K 35/00. Zastosuvannia antyhelmintyka «Brovermektyn-hranuliattm» yak profilaktychno-likuvalnoho zasobu pry ektoparazytozakh koropovykh ryb / lu.V. Loboiko, A.V. Berezovskyi, V.V. Stybel. — u 2011 12742; zaiavl. 31.10.2011; opublik. 11.06.2012, Biul. №11.

12. Pukalo P.la., Bozhyk V.I. (2006). «Nehuvon N» yak profilaktychno-likuvalnyi preparat pry lerneozi koropovykh ryb. Naukovyi visnyk LNAVM imeni S.Z. Hzhytskoho, T. 8, 2 (29), Ch. 1, 140-143.

13. Davydov O.N., Kurovskaya L.Ya., Isayeva N.M. (2001). Ekspress-diagnostika bolezney ryb. Kiyev, MA: Institut zoologii NAN Ukrainy. 